\title{
ZARZĄDZANIE PRODUKCJĄ FILMÓW DLA DZIECI- OGRANICZENIA METOD I NARZĘDZI
}

\section{Abstract \\ CHILDREN'S FILM PRODUCTION - LIMITATIONS ON METHODS AND TOOLS}

The article provides an overview of the available film research methods to strengthen film production management for children aged 4 to 6 years. It diagnoses the limitations of currently used methods and identifies new opportunities related to the development of tools in the field of neuroscience, in particular oculography (eyetracking). The subject of the study is a film for children as a medium of social communication of a wide range. For the purposes of the study, the methods of film research for children used so far were analysed, current needs related to market development were diagnosed and the possibilities of using new tools to measure customer satisfaction were indicated.

Key words: children's film, film production management, children's film evaluation methods, research tools, eyetracking, perception

\section{Wstęp}

Zarządzanie produkcją filmów dla dzieci, tak jak zarządzanie w każdej innej dziedzinie, wymaga systemu wskaźników, które pozwolą na monitorowanie i zbadanie osiągnięcia zadowolenia odbiorcy (Drucker 1998, s. 79-81). Możliwość oceny jakości produktu jest istotna $\mathrm{z}$ punktu widzenia zarówno producenta, instytucji finansującej, jak i osób decydujących o wyświetlaniu filmu dla danej widowni (kin, nauczycieli), a przede wszystkim odbiorców.

Niniejszy artykuł stanowi przegląd dotychczas stosowanych metod badawczych wspomagających zarządzanie produkcją filmów dla dzieci, diagnozuje ich ograniczenia, a także wskazuje na pojawiające się szanse rozwoju i zastosowania 
nowych metod, które pozwolą na bardziej obiektywne monitorowanie i ewaluację rezultatów procesu zarządzania.

Poszerzenie pola nowych metod badawczych ma znaczenie naukowe w obszarze zarządzania mediami, gdyż film dla dzieci jako środek społecznego komunikowania o szerokim zasięgu jest złożonym, a zatem i rzadko podejmowanym przedmiotem badań. Ponadto artykuł ma znaczenie poznawcze, a w przyszłości też aplikacyjne dla producentów filmów dla dzieci. Parafrazując myśl Petera Druckera: „to jest zarządzane, co jest mierzone”, rozwój i wykorzystanie nowoczesnych narzędzi badawczych stanowi kluczowy czynnik przewagi i sukcesu organizacji w rywalizacji o osiągnięcie zadowolenia klienta. Pozyskanie informacji na temat odbioru filmu przez najmłodszą widownię (w wieku 4-6 lat) dostarczy wskazówek, jak prowadzić narrację filmu, porządkować i nadawać sens zjawiskom (wykorzystując filmowy sjużet i styl), tak by młody widz mógł samodzielnie konstruować fabułę. Ze względu na obszar badań i grupę badanych znaczenie implikacji badacza to ważny aspekt rozważań.

\section{Znaczenie filmu dla dzieci jako przedmiotu badań}

Film pozwala dzieciom poznać nowy język - język ruchomych obrazów - i sprawić, że kontakt ze światem będzie bogaty, a proces poznania bardziej różnorodny. Jak wskazują badania Europejskiego Obserwatorium Audiowizualnego (Kanzler 2014), produkcja filmów dla dzieci jest nie tylko narzędziem edukacji czy powodem do dumy, ale także istotnym produktem eksportowym wzmacniającym rodzimą kinematografię. Z tego powodu film dla dzieci w Polsce zaczyna być traktowany przez branżę jako istotny, co potwierdza wprowadzenie odrębnej alokacji na finansowanie kinematografii dziecięcej w Programach Operacyjnych PISF na 2016 rok (PISF 2016).

Film dla dzieci to jednak kosztowna produkcja, która ze względu na słabo zbadaną widownię w wielu kinematografiach narodowych spychana jest na dalszy plan i przegrywa w konkurencji o środki z produkcjami dla dorosłego widza. Ponadto, jak wskazują respondenci badań, film dla dzieci traktowany jest jako „dzieło artystyczne drugiej kategorii”, a twórcy zajmujący się tematyką dziecięcą są zbyt rzadko doceniani (Grawon-Jaksik, Materska-Samek 2016, s. 3).

W Polsce nie prowadzono systematycznych badań na temat rozumienia i odbioru filmu dla dzieci w grupie wiekowej 4-6 lat. Najliczniejszą grupę publikacji w obszarze filmu dla dzieci stanowią opracowania dzieł lub twórców filmowych (Armata 2012; Armata, Wróblewska 2014). Kolejnym wątkiem eksplorowanym w kontekście filmu dla dzieci jest wykorzystanie sztuki w edukacji szkolnej (Depta 1975, 1979, 1980, 1983; Tyszkowa 1979).

Stosunkowo najlepiej przebadaną grupą wiekową są dzieci w wieku 7-12 lat. $\mathrm{W}$ połowie ubiegłego wieku powstały liczne opracowania na temat filmu dla tej 
właśnie grupy dzieci. Opisywały one zachowania widowni, ale także analizowały percepcję filmu (Bauman 1952; Koblewska-Wróblowa 1957, 1960, 1961). Z uwagi na różnice wiekowe oraz liczne czynniki warunkujące rozwój kompetencji medialnych najmłodszych dzieci odniesienie się do wyników tych badań dla grupy wiekowej 4-6 lat nie ma uzasadnienia.

Większość badań i opracowań powstawała w Ośrodku Badawczym Centrali Rozpowszechniania Filmów Oświatowych w Warszawie, który został przekształcony, a następnie zlikwidowany. Tak jak produkcja filmów dla dzieci, tak i badania nad nimi po 1989 roku weszły w fazę kryzysu. Państwowe studia filmowe dotknęło załamanie finansowe, skutkujące między innymi likwidacją niektórych $\mathrm{z}$ nich. Nowe filmy, w tym przeznaczone dla najmłodszych widzów, właściwie przestały powstawać, gdyż wytwórnie, pozbawione państwowych pieniędzy, ograniczyły działalność, a telewizja nie wykazywała zainteresowania rodzimą produkcją. Decyzją Komitetu Kinematografii państwowe studia w Łodzi, Bielsku-Białej, Warszawie i Krakowie oddano do dyspozycji samorządów lub zlikwidowano. Szansą na odrodzenie produkcji filmów dla dzieci stał się Polski Instytut Sztuki Filmowej powołany ustawą z 2005 roku.

Jednostkowe sukcesy kinematografii dla dzieci w Polsce, takie jak Oscar dla animacji Piotruś $i$ wilk Suzie Templeton i nagroda Emmy w kategorii produkcji telewizyjnych dla dzieci i młodzieży dla cyklu Magiczne drzewo Andrzeja Maleszki, wskazują na potencjał produkcji sztuki dla dzieci.

Ponadto Polska posiada dużą widownię tworzącą potencjalny rynek (wewnętrzny) dla polskich produkcji dla dzieci (Grawon-Jaksik, Materska-Samek 2016; Kanzler 2014). Widownia europejskich filmów dla dzieci w widowni ogółem w Polsce stanowi średnią europejską i wynosi $11 \%$. Oznacza to, że popyt na rodzime filmy dla dzieci nie odbiega od popytu notowanego w pozostałych krajach Europy, a biorąc pod uwagę niewielką produkcję (1\%), pozostałe $10 \%$ widowni ogląda europejskie produkcje dla dzieci, gdyż w repertuarach kin nie znajdują atrakcyjnych polskich tytułów.

Wydzielenie w 2016 roku osobnej alokacji ukierunkowanej na rozwój filmu dla dzieci obfituje co roku w nowe projekty filmów (Rozwój polskiego kina familijnego..., PISF 2018), które mają ograniczone możliwości korzystania z wiedzy i warsztatu poprzedników. Stanowi to kluczowe uzasadnienie potrzeby realizacji badań filmu dla dzieci, gdyż ogromna zapaść, która nastąpiła po 1989 roku, a w konsekwencji nieliczna produkcja filmów dla dzieci sprawiły, że „sztuka filmu dziecięcego przestała być dziedziczona: ani twórcy, ani ich dzieła nie dialogują ze sobą, wynosząc z tej dyskusji wnioski i wartości artystyczne" (Armata, Wróblewska 2014), zatem rozwiązaniem tej niekorzystnej sytuacji może być naukowe opracowanie tematu filmów dla dzieci.

W kontekście możliwości zastosowania wyników badań filmu dla dzieci należy także zwrócić uwagę na fakt, że w Polsce nie istnieje oficjalny system oceny filmów (tzw. Rating), który z jednej strony pomagałby producentom skuteczniej 
kierować swoje filmy do grup docelowych, a z drugiej chroniłby prawidłowy fizyczny, psychiczny i moralny rozwój małoletniej widowni kinowej przed nieodpowiednim wpływem filmów. Jedyny system oceny treści audiowizualnych pod względem przeznaczenia wiekowego $\mathrm{w}$ Polsce stosowany jest $\mathrm{w}$ odniesieniu do programów telewizyjnych (Rozporządzenie KRRiT z dn. 23.06.2005 r.) oraz gier komputerowych (PEGI - Pan European Game Information, tłum. Ogólnoeuropejski System Klasyfikacji Gier, OSKG). Zatem badania filmu dla najmłodszych widzów mogą stanowić istotny przyczynek do dyskusji prowadzonej między innymi przez Rzecznika Praw Dziecka oraz Sieć Kin Studyjnych i Lokalnych na temat uregulowania dostępu do treści filmowych ze względu na wiek i dojrzałość odbiorców.

\section{Luka badawcza}

Stosowane narzędzia i techniki zarządzania produkcją filmową nie korzystają z nowych osiągnięć, „badania naukowe dotyczące stosowania metod zarządzania w praktyce kinematografii światowej są ograniczone”, a także „brakuje owych badań na rynku polskim" (Kotlińska, s. 3-5). Ponadto film dla dzieci to słabo opracowane pole badawcze. Brak zainteresowania filmem dla dzieci zarówno ze strony twórców, jak i naukowców wynika z wielu czynników. Wśród nich dominuje niski prestiż tematyki, ale również specyficzna wiedza z zakresu rozwoju wieku dziecięcego, a w przypadku naukowców ograniczone instrumentarium badawcze. W paradygmacie pozytywistycznym, stosując indukcję, pojawia się problem stawiania wielu hipotez i ukierunkowania na ich weryfikację, co pociąga za sobą ograniczenie wiedzy i wyobraźni badacza. Badacz, stosując indukcję zamiast twórczego poszukiwania i budowania wiedzy na podstawie otrzymanych wyników, ogranicza pole do weryfikacji postawionych hipotez, co niesie ze sobą możliwość nieświadomego działania na rzecz uprawomocnienia (uprawdopodobnienia) wyników badań.

Ponadto, biorąc pod uwagę brak opracowania pola badawczego, sięganie po metody ilościowe nie znajduje uzasadnienia. Badania najmłodszej widowni w wieku 4-6 lat wymagają odpowiedniego przygotowania psychologicznego i mają charakter jakościowy. Biorąc pod uwagę, że celem badań jest to, w jaki sposób dzieci doświadczają, interpretują, rozumieją, percypują czy konceptualizują prowadzoną $\mathrm{w}$ filmach narrację, należy przyjąć perspektywę fenomenograficzną. Rozstrzygnięcie będzie wymagało odniesienia się do pewnych mentalnych fenomenów z zakresu teorii umysłu (theory of mind). Bliższa analiza pytań badawczych wskazuje na istotną trudność, bowiem ani znajomość ogólnych cech ludzkiego umysłu, ani też wiedza na temat narracji filmowej, ani nawet kombinacja ich obu nie dostarczy bezpośrednio odpowiedzi na zadane pytania.

Dotychczas dostępne metody badania dzieci tej grupy wiekowej były stosowane na gruncie nauk psychologicznych i w pedagogice oraz ograniczały się do wywiadów wspomaganych różnego rodzaju aktywnością plastyczną (action research). 
Skutkowało to wysokim poziomem implikacji badacza zarówno w działania respondenta, jak i kodowanie oraz interpretację wyników. Interpretatywne metody cechuje subiektywizm wynikający $\mathrm{z}$ indywidualnej oceny przez badacza, a w przypadku interpretacji odpowiedzi czy zachowań dzieci pojawia się dodatkowy problem perspektywy osoby dorosłej.

Trudno jest zatem uniknąć perspektywy osoby dorosłej dotyczącej konceptualizacji narracji postrzeganej przez dzieci. $Z$ tych powodów niezbędne są poszukiwania bardziej obiektywnych metod badania filmu kierowanego do najmłodszych widzów.

\section{Nowe metody badań}

Od kilku lat rozwijają się metody pozwalające ograniczyć wpływ respondenta i badacza na otrzymane wyniki. Zastosowanie nowoczesnych metod i narzędzi z zakresu neuronauki, które dotychczas nie były używane w kontekście badania filmu dla dzieci, daje nowe możliwości opracowania tego pola badawczego. Użycia mieszanej metody badań jakościowych bazującej na badaniu percepcji z wykorzystaniem eyetrackerów i pogłębionych wywiadów zarówno retrospektywnych (retrospective think aloud, RTA), indywidualnych (IDI), jak i grupowych (FGI) na dzieciach w wieku 4-6 lat nie podjęto jeszcze w Polsce. Na świecie takie badania na dzieciach stosowano $\mathrm{w}$ odniesieniu do percepcji ekspozycji muzealnych, gier edukacyjnych i multimediów (Jung, Zimmerman, Pérez-Edgar 2018).

Trudno określić początek stosowania badań okulograficznych (eyetrackingowych). Nicholas J. Wade i Benjamin W. Tatler (2005) poszukiwali pierwszych wzmianek o badaniach oczu i wykazali, że ruchy oka ciekawiły badaczy od zarania dziejów. W monografii Johannesa Müllera opublikowanej w 1826 roku znajdujemy pierwszy opis regularnych badań tego typu. Zainteresowanie pierwszych badaczy używających metod okulograficznych koncentrowało się bardziej na fizycznych aspektach ruchu gałki ocznej, takich jak optyka, fizjologia i budowa oka, niż na procesach poznawczych, które stoją za tym ruchem.

Obszarem badań prowadzonych współcześnie są procesy poznawcze stojące za ruchem oka. Rejestrując liczbę fiksacji, ich długość, sakkady i ścieżki ruchu gałki ocznej, dzięki wykorzystaniu najnowszych technologii korelujemy te wyniki z oglądanym obrazem, poznajemy obszary zainteresowań (tzw. area of interest, AOI) lub otrzymujemy informację o czasie reakcji, „trafieniach” w cel czy popelnionych błędach.

W Polsce badania eyetrackerami w naukach o sztuce rozwijają się intensywnie na gruncie neurokognitywnej teorii obrazu (Francuz 2013, 2012; Francuz, Jędrzejewski 2010). To właśnie płaski obraz stanowił pierwszy przedmiot badań metodami okulograficznymi na gruncie sztuki, które podjął Piotr Francuz i opisał w swojej książce Imagia. Jego badania obejmowały 24 uczestników i była to pierwsza w Polsce próba wykorzystania narzędzi okulograficznych do analizy malarstwa. 
Czynniki wpływające na proces postrzegania obrazu zarówno statycznego, jak i dynamicznego (moving pictures) można podzielić na te, które są poza naszą kontrolą (egzogenne) oraz podlegające naszej świadomości i kontroli (endogenne). Oba typy są wykorzystywane przez fotografów, operatorów czy realizatorów obrazu, jednak pierwsze - jako niezależne od naszej świadomości, wiedzy, kontekstu kulturowego czy osobniczych uwarunkowań i preferencji - są skuteczniejszym narzędziem kierowania spojrzenia. Wzrok widza prowadzony jest dzięki elementom kompozycji, tj. wyróżnienie kolorem, oświetleniem czy kadrowaniem, a w przypadku filmu także dzięki ujęciom poprzez zbliżenie, zastosowanie głębi ostrości (focus), ruchom kamery (zoom) czy finalnie odpowiednim cięciom i montażowi.

Dotychczas nikt z polskich badaczy sztuki wykorzystujących metodę eyetrackingu nie objął badaniami filmu. Wynika to $\mathrm{z}$ faktu wewnętrznego ruchu, niezależnego od widza, który w dużym stopniu warunkuje postrzeganie. Uwaga jest istotnie skorelowana $\mathrm{z}$ występującym w scenach wewnętrznym ruchem, który pozostaje powiązany $\mathrm{z}$ punktem zainteresowania (AOI). Punktami zainteresowania bardzo często są osoby w interakcji z innymi ludźmi, jako że twarz ludzka (a dokładniej: trójkąt wytyczony przez oczy i usta) stanowi element obrazu najczęściej podlegający fiksacji.

Celem producentów filmów jest osiągnięcie zamierzonego efektu w postaci synchronicznego postrzegania filmu przez widzów (attentional synchrony). Jak to określił Steven Spielberg w wywiadzie dla „The Sunday Times”: „Przechodzimy do pewnego poziomu zaangażowania, gdy oglądając mecz tenisa, widzimy idealną synchronizację wzroku w lewo-prawo, lewo-prawo. To samo ma miejsce w kinie, kiedy film działa, a publiczność skupia swoją uwagę, prawie zahipnotyzowana, wszyscy oglądają te same rzeczy, wszyscy wiedzą, gdzie patrzeć dokładnie w tym samym czasie... to cudowna rzecz. Nie ma nic wspanialszego od tego" (Steven Spielberg Loves Cinema 2013, tłum. własne). Badania percepcji filmu z zastosowaniem metod okulograficznych dają zatem szansę zweryfikowania, czy zamierzenia producentów dotyczące masowego kierowania uwagi widzów zostały osiągnięte.

Twórcy ze względu na liczne ograniczenia nie sięgają do badań widowni i realizują produkcję w sposób intuicyjny. Przykładem takiej intuicyjnej praktyki jest montaż filmu umożliwiający widzowi odpoczynek oczu przez mrugnięcie powiekami w momencie cięć, co umożliwia utrzymanie skupienia na prowadzonej narracji (Murch, Favreau). Poczucie ciągłości akcji pomimo zwiększenia liczby scen, skrócenia ujęć i zastosowania szybszego montażu potwierdziły badania Tima J. Smitha (2013) prowadzone z zastosowaniem eyetrackingu na filmach dwuwymiarowych w grupie dorosłych widzów. Smith należy do nielicznych badaczy na świecie, którzy w swoich studiach nad percepcją filmu wykorzystują metody okulograficzne. Na podstawie uzyskanych wyników sformułował teorię ciągłości filmowej (attentional theory of cinematic continuity), w której wykazuje, że dobierane przez twórców narzędzia służą osiągnięciu synchronicznego postrzegania przez widzów (attentional synchrony), a w konsekwencji prowadzą do spójnego odbioru filmu. Należy 
zauważyć, że w swoich badaniach wykorzystuje on fragmenty filmów gatunkowych, a badania prowadził na dorosłych respondentach, dlatego niekoniecznie znajdują zastosowanie do filmów autorskich czy filmów dla dzieci.

\section{Ograniczenia percepcji filmu przez dzieci}

W naturze doświadczamy większej percepcji głębi niż w filmie i o ile na ekranie wykorzystuje się ten sam mechanizm: odległe obiekty wydają się mniejsze, a bliższe obiekty mogą zasłaniać dalsze obiekty, o tyle metody postrzegania głębi, takie jak paralaksa ruchowa czy stereopsja, są tu ograniczone. Stereopsja to zdolność widzenia przestrzennego przez mózg postrzegający głębię poprzez połączenie kątowo odmiennych obrazów uzyskanych z obu oczu. Druga metoda percepcji głębi to paralaksa ruchowa, uzyskana $w$ wyniku poruszania głową lub ciałem: kiedy poruszamy głową, obiekty bliższe wydają się poruszać razem z nami szybciej niż bardziej odległe obiekty. Żaden z tych efektów nie występuje podczas normalnego oglądania filmu na płaskim ekranie, chociaż doświadczenie paralaksy ruchu może być symulowane ruchem kamery. Jeśli na przykład kamera zbliża się nagle do obiektu, refleksowa reakcja obronna widza nie jest już tak prawdopodobna, jak działoby się to w rzeczywistości. Bez bogatej percepcji głębi ruch na ekranie (szczególnie w kierunku i od aparatu) nie jest tak przekonujący jak w prawdziwym życiu.

Przestrzeń trójwymiarowa w filmie - zarówno stereoskopia (3D), jak i wirtualna rzeczywistość (Cinamatic VR) - potęguje wpływ ruchu, a przez to subiektywne doświadczenie widzenia. Przedmiot oglądany w przestrzeni trójwymiarowej może być oglądany zarówno za pomocą widzenia stereoskopowego (3D), generowany w polu między widzem a ekranem, jak i w wirtualnej przestrzeni, umożliwiającej pomimo centralnego położenia zmianę punktów widzenia (Cinematic VR). Stwarza to zupełnie nowe możliwości interpretacyjne w porównaniu do badań prowadzonych z wykorzystaniem filmów oglądanych na ekranie. Badanie przekazów trójwymiarowych narzuca zatem konieczność uwzględnienia położenia obserwatora, jego ruchu, a także wielu charakterystyk związanych z jego cechami osobniczymi. Sytuacje dodatkowo komplikuje problem percepcji przestrzeni trójwymiarowej, generowanej przez nowoczesne technologie. Podobnie jak widzenie ruchu w filmie opiera się na zupełnie innych zasadach niż widzenie ruchu rzeczywistego, tak doświadczenie przestrzeni trójwymiarowej w kinie (3D), wirtualnej rzeczywistości (VR) i w świecie realnym wykorzystuje różne mechanizmy widzenia. Mimo że produkowany jest już sprzęt i oprogramowanie umożliwiające prowadzenie badań okulograficznych w przestrzeni wirtualnej, dotychczas na gruncie zarządzania czy nauk o mediach nie opublikowano wyników takich badań.

Innym interesującym wątkiem $\mathrm{z}$ punktu widzenia niniejszego opracowania są ograniczenia badań wynikające $\mathrm{z}$ zaangażowania respondenta dziecięcego. By móc prowadzić badania postrzegania filmów przez dzieci, konieczna jest analiza 
czynników, które mogą istotnie wpływać na postrzeganie filmu, a związane są zarówno $\mathrm{z}$ rozwojem zmysłu wzroku, jak i mentalizacją czy finalnie technicznymi możliwościami realizacji badań. Rozwój widzenia u dzieci jest stosunkowo młodą dziedziną, a większość badań pochodzi z ostatnich dziesięcioleci. Ostrość widzenia u dzieci rozwija się od noworodka i w wieku trzech lat uzyskują one jej pełny zakres. Jednak z punktu widzenia i rozpoznania formy pełną wartość dzieci osiągają dopiero po około pięciu latach, a wartość szczytową po około 8-10 latach (Drover i in. 2008).

Podobnie jak w przypadku większości parametrów widzenia rozwijają się: widzenie stereoskopowe, czułość kontrastu czy kolorów. Wrażliwość na kontrast jest słaba u małych dzieci, ale poprawia się gwałtownie $\mathrm{z}$ wiekiem (Atkinson, Braddick, Moar 1977; Norcia i in. 1989). Wysokie wartości obserwuje się około 3.-5. roku życia, aby zbliżyć się do wartości dorosłych około 7. roku życia. Czułość kolorów wzrasta liniowo, aż do około 4.-6. roku życia. Przetestowane w warunkach gier wideo badania wykazały jednak, że sześciolatki pozostają nieco mniej wrażliwe na kolory niż dorośli (Abramov i in. 1984). Z uwagi na ryzyko niepełnego rozwoju widzenia u dzieci w wieku 4-6 lat należy uwzględnić ten aspekt w projektowaniu i analizie otrzymanych wyników badań na najmłodszych widzach.

Kolejna grupa czynników warunkujących postrzeganie i rozumienie filmu przez dzieci jest związana z mentalizacją. Ekran definiuje przestrzeń, która nie jest bezpośrednio dostępna dla dziecka poza oglądaniem - nie może wejść ani działać na przestrzeni ujawnionej przez ekran, chociaż może to dla niego nie być oczywiste (Pierroutsakos, Troseth 2003).

Film jest konstruowany jako sekwencyjny montaż ciągłych ujęć o różnym charakterze i długości. Współcześnie, dzięki nowym, lekkim i wygodnym do operowania kamerom, ułatwione jest wykonywanie wielu różnych ujęć. Tym samym przejście następuje coraz częściej, a jego częstotliwość w ostatnich 75 latach przyśpieszyła od kilkunastu do kilku sekund (Cutting i in. 2011, s. 572). Mogą być one tak koncepcyjnie proste, jak zmiana kąta kamery w tej samej scenie, lub tak złożone, jak przejście do wyobraźni fikcyjnej postaci, w inny czas i inne miejsce. Aby sekwencyjnie zrozumieć narrację, widz musi interpretować każde przejście.

Dzieci mają problem $\mathrm{z}$ analizą filmu właśnie ze względu na trudności w odpowiedzi na takie pytania jak:

- Czy ustawienie jest takie samo jak wcześniej?

- Czy postacie i przedmioty są takie same?

- Czy czas jest taki sam? Jeśli znaki lub ustawienia nie były wcześniej widziane, należy zauważyć nowość; jeśli były wcześniej widziane, jaka jest ich rola w rozwijającej się narracji?

- Czy trwające działania są kontynuacją poprzednich? Co o tym świadczy?

Wynika to $\mathrm{z}$ braku wcześniejszego doświadczenia w oglądaniu filmów, a także rozwiniętych funkcji poznawczych związanych z krótkotrwałą pamięcią wzrokową i słuchową oraz umiejętnością wnioskowania. 
Zrozumienie postrzeganego filmu wymaga wnioskowania o ciągłości i nieciągłości przestrzeni, czasu, akcji, intencji postaci, psychologii postaci i wielu innych. Ponadto wymaga ogólnej wiedzy o świecie (np. interpretacja symboli), a także rozumienia (teoria umysłu), że inni ludzie mają wyraźne i indywidualne intencje, wspomnienia, doświadczenia.

\section{Wspomaganie rozumienia filmu przez dźwięk}

Film i telewizja to złożone media. Oba istniały zawsze jako połączenie informacji wizualnych i dźwiękowych. Nawet wczesne nieme filmy prawie zawsze były przedstawiane $\mathrm{z}$ akompaniamentem muzycznym na żywo lub $\mathrm{z}$ narratorem. Brakuje badań empirycznych nad tym, jak połączenie wkładu audio i wizualnego wpływa na to, jak postrzegamy filmy, a zwłaszcza nad sposobem, w jaki na nie zwracamy uwagę. Naukowcy, kompozytorzy, reżyserzy i widzowie zawsze domyślnie wierzyli, że muzyka filmowa pomaga w skupienia uwagi wizualnej publiczności, jednak nie istniały narzędzia badawcze mogące udowodnić tę hipotezę empirycznie. Badania okulograficzne pozwalają śledzić wzrok, by zbadać wpływ kontekstowych atrybutów muzycznych na uwagę wzrokową podczas seansu. Wyniki prowadzonych badań na czterech dorosłych widzach filmu Szeregowiec Ryan (Redmond i in. 2016) pokazują, że muzyka jest $\mathrm{w}$ stanie kierować naszą uwagę na obszary zainteresowania (AOI), a także wydłużać fiksacje i zachęcać do eksploracji wybranych scen wizualnych. Redmond i in. przeprowadzili eksperyment, by określić wpływ przyczynowo-skutkowy dźwięku (zmienna niezależna) na zachowanie widza będące przedmiotem zainteresowania (zmienna zależna). Po usunięciu zmiennej niezależnej porównali postrzeganie tej samej sceny i poprzez wnioskowanie określili wpływ owej manipulacji. Biorąc pod uwagę, że badacze zmanipulowali czynnik krytyczny, tj. obecność dźwięku, można się zastanawiać, czy ich badanie wniosło nową wiedzę o wpływie dźwięku na spojrzenie podczas oglądania filmu. Aby to zbadać, wybrali dwie tradycyjne metody wyrażania danych o spojrzeniu: analizę i rozproszenie obszaru zainteresowania (AOI). Korzystając z dziewięciu statycznych (w stosunku do ekranu) AOI, byli oni w stanie obliczyć, ile czasu spędził wzrok w każdym AOI, i wykorzystać tę miarę do ustalenia, jak rozproszone było spojrzenie we wszystkich AOI. Analiza wykazała większe rozproszenie w stanie ciszy w porównaniu do próby z dźwiękiem i niewielką liczbę znaczących różnic w ilości czasu spędzonego w niektórych obszarach w wersji udźwiękowionej. To pierwsze badania procesów percepcji audiowizualnej w działaniu za pomocą eyetrackingu, które pomagają w zrozumieniu tego zjawiska, jednak obecnie powinno się poszukiwać odpowiedzi na pytania co do sposobu kształtowania uwagi wzrokowej przez muzykę.

W przypadku osób dorosłych, a zwłaszcza w odniesieniu do dzieci należy jednak pamiętać, by ostrożnie przypisywać znaczenie fiksacji. Interpretacja jakościowa poszczególnych miejsc fiksacji, ścieżek skanowania lub grupowych map cieplnych 
jest przydatna $\mathrm{w}$ początkowej interpretacji, ale nie należy przyjmować, że fiksacja jest równa świadomości (Smith, Lamont, Henderson 2012, s. 490-491). Osoby dorosłe potrzebują minimalnie $60-80 \mathrm{~ms}$, by zarejestrować obraz, a dopiero przy fiksacjach powyżej 150 ms można przyjąć, że są świadome postrzegania obrazu. W kontekście badania dzieci w wybranych grupach wiekowych, w tym w wieku 4-6 lat, brakuje danych na temat czasu niezbędnego do zarejestrowania obrazu.

Dla dzieci efekty dźwiękowe mogą dawać wskazówki co do treści, a przede wszystkim ich zmian, a te mogą być szczególnie skuteczne w przyciąganiu uwagi wizualnej do ekranu. Trzeba jednak zwrócić uwagę, że podobnie jak wyświetlane obrazy, również dźwięk jest inny niż w codziennym życiu. W zależności od warunków seansu może mieć on ograniczoną jasność, częstotliwość, zakres i dynamikę wynikające z technicznych ograniczeń rejestrowania i odtwarzania.

Nagrany dźwięk i projekcja są też ograniczone w oddaniu pełnego zakresu przestrzennego. Badania eyetrackingowe filmu najczęściej realizowane są przed monitorem (np. komputera) i nawet $\mathrm{z}$ nowszymi technologiami dźwięku przestrzennego nie mają możliwości oddać specyfiki naturalnego rozchodzenia się fal od źródeł dźwięku.

Jednym z pierwszych zadań stojących przed dziećmi, niezbędnym, by wykorzystać dźwięk do lepszej percepcji filmu, jest uświadomienie, że dźwięk pozostaje związany z obrazem. Choć wydaje się to oczywiste, należy zauważyć, że w przypadku monofonicznej technologii nie ma żadnych przestrzennych wskazówek dźwiękowych dotyczących tego, z jakiego źródła na ekranie pochodzi dźwięk. Można wnioskować, że postać po lewej stronie ekranu wydaje dźwięki, bo porusza ustami, ale nawet przy współczesnym dźwięku stereo i surround, które zapewniają pewien poziom rozdzielczości przestrzennej słuchu, istnieje duża ilość dźwięku, który nie jest bezpośrednio zsynchronizowany z żadną akcją na ekranie, na przykład efekty dźwiękowe z wydarzeń rozgrywających się poza ekranem i muzyczne podkreślenia. Oprócz dialogów postaci i narracji, audio ma wiele zastosowań w produkcjach filmowych. Podkreślenia muzyczne służą do wpływania na nastrój i reakcje emocjonalne u widzów. Dźwięki charakterystyczne są często stosowane w celu zapewnienia wyrazistej atmosfery i poczucia obecności. Tych środków prowadzenia narracji zwłaszcza najmłodsze dzieci muszą się najpierw nauczyć, zanim będą je wykorzystywać do lepszego postrzegania filmu.

\section{Zakończenie}

Zastosowanie nowej metody badawczej w kontekście filmu dla dzieci otwiera możliwości badań projektów filmowych i medialnych, które dotąd były ograniczone. Przypomnijmy, że dotychczas wykorzystywano jedynie takie metody jak wywiady indywidualne (IDI) i zogniskowane wywiady grupowe (FGI). Badania eyetrackingowe nie są rozwiązaniem kompleksowym i dlatego bywają krytykowane. Mają one liczne ograniczenia. Przede wszystkim pomijają „marginalnych” widzów lub 
marginalne sposoby oglądania filmów, które zyskują coraz większe zainteresowanie badaczy. Mogą się odnosić do filmu jako medium masowego, gwarantującego jednolitość oglądania, a w bardzo ograniczonym zakresie odnoszą się do filmu postrzeganego jako dzieło sztuki. Wielu badaczy zarzuca im, że dostarczają jedynie truizmów i utwierdzają w już znanych faktach.

Aby jednak zminimalizować ograniczenia poszczególnych metod, można je połączyć i wzajemnie weryfikować. Do rozwiązania wielu problemów badawczych może służyć triangulacja metod obejmująca:

- badania okulograficzne (eyetrackingu);

- wywiady RTA (retrospective think aloud) wspomagane zadaniami plastycznymi i dające perspektywę deklaratywną od dziecięcych widzów co do postrzeganych treści;

- wywiady IDI z twórcami filmów;

- analizę ekspercką otrzymanych wyników badań dzieci w kontekście założeń artystycznych i produkcyjnych badanych filmów.

Takie połączenie metod pozwoli otrzymać kompleksowy materiał badawczy i zminimalizować subiektywność, która stanowi nieodłączną cechę badań interpretatywnych.

Świadomość badacza dotycząca jego wpływu na przedstawienie wyników ma istotne znaczenie na jakość analizy i rygor naukowy. Tak jak w naukach historycznych, w badaniach mediów i filmu dla dzieci ogranicza nas nasza perspektywa - „prezentyzm", który popełniamy wtedy, gdy prowadzimy badania i nie przestrzegamy zasady, aby rozpatrywać kwestie społeczne we właściwym im kontekście, a do oceny działań nie używać naszych współczesnych standardów. Interpretacja i analiza otrzymanych wyników w przypadku badania filmu dla dzieci uzależnione są od różnic wiekowych (pokoleniowych!), kulturowych, a nawet językowych, biorąc pod uwagę, że użycie danego języka także wpływa na odbiór opisywanej za jego pomocą rzeczywistości (Sapir 1978).

Niemożliwa jest obiektywna wiedza o percepcji narracji filmu dla dzieci, zaś ustalenie wskaźników wspomagających zarządzanie produkcją pozostaje utrudnione. Jednak dzięki rozwojowi eyetrackerów (nowych instrumentów do badań okulograficznych) i triangulacji zastosowanych metod można uzyskać bardziej obiektywnie informacje służące producentom do oceny zadowolenia odbiorców. Uwarunkowania percepcji filmu w zależności od grup wiekowych oraz schematów poznawczych widzów stanowią bardzo szerokie pole badawcze, które wymaga dalszej eksploracji. Podjęcie tego zadania pozwoli nie tylko na rozwój nauki, ale będzie też bazą do analiz porównawczych różnych sposobów prowadzenia narracji i eksperymentów bazujących na odbiorze modyfikacji materiałów audiowizualnych. Zastosowanie osiągnięć nauki dostarczy zarządzającym systemu wskaźników, a przez to wzmocni zarządzanie produkcją filmów dla dzieci i zadowolenie odbiorców. Finalnie odbiorcy otrzymają wartościową propozycję, przekładającą się na rozwój młodych pokoleń poprzez uczestnictwo w kulturze i dopasowaną do potrzeb edukację medialną. 
Podjęcie tej tematyki jest istotne także z punktu widzenia pozyskania i wydatkowania środków wspierających produkcję filmów dla dzieci. Dzięki zastosowaniu nowoczesnych metod badawczych mecenasi i instytucje finansujące (np. Polski Instytut Sztuki Filmowej) otrzymają potwierdzenie wysokiej jakości zarządzania produkcją, której ostatecznym celem jest zadowolenie grup docelowych.

Projekt finansowany w ramach programu Ministra Nauki i Szkolnictwa Wyższego pod nazwa „Regionalna Inicjatywa Doskonałości” w latach 2019-2022, nr projektu 023/RID/2018/19, kwota finansowania 11865100 zł

\section{Bibliografia}

Abramov I., Hainline L., Turkel J., Lemerise E., Smith H., Gordon J., Petry S. (1984), Rocket-ship psychophysics. Assessing visual functioning in young children, „Investigative Ophthalmology and Visual Science”, nr 25(11), s. 1307-1315.

Armata J. (2012), 65 lat polskiej animacji dla dzieci, Łódź: Polski Instytut Sztuki Filmowej, Muzeum Kinematografii w Łodzi.

Armata J., Wróblewska A. (2014), Polski film dla dzieci i młodzieży, Warszawa: Fundacja Kino.

Atkinson J., Braddick O.J., Moar K. (1977), Development of contrast sensitivity over the first three months of life in the human infant, „Vision Research”, nr 17, s. 1037-1044.

Babbie E. (2004), Badania społeczne w praktyce, Warszawa: Wydawnictwo Naukowe PWN.

Bauman J. (1952), Analiza form zachowania dzieci w wieku 7-12 lat w czasie ogladania filmów. Na podstawie materiałów zebranych przez zespót „Dziecko i film” podczas II międzynarodowego Konkursu Filmów Rozrywkowych dla Dzieci, Warszawa: Ośrodek Badawczy Centrali Rozpowszechniania Filmów Oświatowych.

Bordwell D. (1985), Narration in the Fiction Film, Madison: University of Wisconsin Press.

Bordwell D. (1989), Making Meaning: Inference and Rhetoric in the Interpretation of Cinema, Cambridge: Harvard University Press.

Creswell J.W. (2013), Projektowanie badań naukowych. Metody jakościowe, ilościowe i mieszane, Kraków: Wydawnictwo Uniwersytetu Jagiellońskiego.

Cutting J.E., Brunick K.L., DeLong J.E., Iricinschi C., Candan A. (2011), Quicker, faster, darker: Changes in Hollywood film over 75 years, „i-Perception”, nr 2, s. 569-576.

Denzin N.K., Lincoln Y.S. (red.) (2009), Metody badań jakościowych, t. 1, Warszawa: Wydawnictwo Naukowe PWN.

Depta H. (1975), Film i wychowanie, Warszawa: WSiP.

Depta H. (1980), Analiza i interpretacja filmu w szkole, Warszawa: WSiP.

Depta H. (1983), Film w życiu i wychowaniu młodzieży, Warszawa: Wydawnictwo Uniwersytetu Warszawskiego.

Depta H. (1986), Fabryka snów czy szkoła życia, Warszawa: Centralny Ośrodek Metodyki Upowszechniania Kultury.

Depta H. (1979), Kultura filmowa - wychowanie filmowe, Warszawa: WSiP.

Drover J.R., Felius J., Cheng C.S., Morale S.E., Wyatt L., Birch E.E. (2008), Normative pediatric visual acuity using single surrounded HOTV optotypes on the Electronic Visual Acuity Tester following the Amblyopia Treatment Study protocol, „Journal of American Association for Pediatric Ophthalmology and Strabismus", nr 12(2), s. 145-149. Dostęp online: https:// www.ncbi.nlm.nih.gov/pubmed/18155943. 
Drucker P. (1998), Praktyka zarządzania, Warszawa: Nowoczesność, Akademia Ekonomiczna w Krakowie, Czytelnik.

Duchowski A.T. (2007), Eyetracking Methodology: Theory \& Practice. 2nd Edition, London: Springer-Verlag.

Francuz P. (2010), Na ścieżkach neuronauki, Lublin: Wydawnictwo KUL.

Francuz P. (2012), Komunikacja wizualna, Warszawa: Wydawnictwo Naukowe Scholar.

Francuz P. (2013), Imagia. W kierunku neurokognitywnej teorii obrazu, Lublin: Wydawnictwo KUL.

Francuz P., Jędrzejewski S. (2010), Nowe media i komunikacja wizualna, Lublin: Wydawnictwo KUL.

Gębicka E. (2006), Między państwowym mecenatem a rynkiem. Polska kinematografia po 1989 roku w kontekście transformacji ustrojowej, Katowice: Wydawnictwo Uniwersytetu Śląskiego.

Grawon-Jaksik A., Materska-Samek M. (2016), Czy kinematografia kręci się wokół dzieci? Kondycja kinematografii dla dzieci i analiza uwarunkowań edukacji filmowej dzieci do 12 roku zycia, Kraków: Fundacja Rozwoju Kina.

Guilford J.P. (2005), Rzetelność i trafność pomiarów, [w:] J. Brzeziński (red.), Trafność i rzetelność testów psychologicznych. Wybór tekstów, Gdańsk: Gdańskie Wydawnictwo Psychologiczne.

Hatch A.J. (2007), Early Childhood Qualitative Research, New York: Routledge.

Helman A., Ostaszewski J. (2007), Historia myśli filmowej. Podręcznik, Gdańsk: Słowo/Obraz Terytoria.

Hendrykowski M. (1994), Polski film fabularny dla dzieci i młodzieży, Poznań: Ogólnopolski Ośrodek Sztuki dla Dzieci i Młodzieży.

Howarth P.A. (2011), Potential hazards of viewing 3-D stereoscopic television, cinema and computer games: a review, „Ophthalmic and Physiological Optics”, nr 31(2), s. 111-122.

Jung Y.J., Zimmerman H.T., Pérez-Edgar K. (2018), A Methodological case study with mobile eye-tracking of child interaction in a science museum, „TechTrends”, nr 62, s. 509-517.

Kaiser Z. (1960), Komizm w filmach dla dzieci, Warszawa: Ośrodek Badawczy Centrali Rozpowszechniania Filmów Oświatowych.

Kanzler M. (2014), The Theatrical Circulation of European Children's Films, Strasbourg: European Audiovisual Observatory.

Koblewska-Wróblowa J. (1957), Dzieci w kinie, Warszawa: Wiedza Powszechna.

Koblewska-Wróblowa J. (1960), Rozumienie przez dzieci z klas I-IV filmów animowanych, Warszawa: Ośrodek Badawczy Centrali Rozpowszechniania Filmów Oświatowych.

Koblewska-Wróblowa J. (1961), Film i dzieci, Warszawa: Wydawnictwa Artystyczne i Filmowe.

Kulik A. (1962), Mój film. Z badań nad upodobaniami filmowymi dzieci w wieku od 7 do 14 lat, Warszawa: Nasza Księgarnia.

Kurwinkel T., Schmerheim P. (2014), The Significance of Sound Design Regarding Children as Addressed Audience, University of Bremen, dostęp online: http://www.kids-regio.org/fileadmin/downloads/english/KIDS_Regio_2014_The_Significance_of_Sound_Design_Regarding_Children_as_Addressed_Audience_Kurwinkel_and_Schmerheim.pdf.

Kvale S. (2010), Prowadzenie wywiadów, Warszawa: Wydawnictwo Naukowe PWN.

Manituk R., Bazylik B. (2014), Dokładność pomiaru kierunku patrzenia, [w:] S. Grucza, M. Płużycka, P. Soluch (red.), Widziane inaczej. Z polskich badań eyetrackingowych, Warszawa: Instytut Kulturologii i Lingwistyki Antropocentrycznej UW.

Moroz J. (2013), Fenomenografia jako metoda badania treści świadomościowych, „Pedagogika Szkoły Wyższej”, nr 1, s. 33-44.

Murawska-Najmiec E. (2011), Systemy ochrony małoletnich $w$ programach telewizyjnych $i$ radiowych w wybranych krajach europejskich - Francja, Belgia, Niemcy, Wielka Brytania, We gry, Holandia i Szwecja, Warszawa: KRRiT. 
Nierenberg B. (2015), Badanie reklamy, [w:] B. Nierenberg (red.), Zarzadzanie reklama, Kraków: Wydawnictwo Uniwersytetu Jagiellońskiego, s. 39-56.

Nierenberg B. (2015), O potrzebie humanistycznego zarządzania mediami, [w:] B. Nierenberg, R. Batko, Ł. Sułkowski (red.), Zarządzanie humanistyczne, Kraków: Wydawnictwo Uniwersytetu Jagiellońskiego, s. 107-121.

Nierenberg B. (2017), O zarzadzaniu mediami uwag kilka, [w:] A. Adamski, S. Gawroński, M. Szewczyk (red.), Nauki o mediach i komunikacji społecznej. Krystalizacja dyscypliny w Polsce: tradycje, nurty, problemy, rezultaty, Warszawa-Rzeszów: Oficyna Wydawnicza ASPRA, s. 271-282.

Norcia A.M., Tyler Ch.W., Hamer R.D., Wesemann W. (1989), Measurement of spatial contrast sensitivity with the swept contrast VEP, „Vision Research”, nr 29(5), s. 627-637.

Ostaszewski J. (2016), Film: na styku fikcji i rzeczywistości organizacyjnej, [w:] M. Kostera, B. Nierenberg (red.), Komunikacja społeczna w zarządzaniu humanistycznym, Kraków: Wydawnictwo Uniwersytetu Jagiellońskiego, s. 137-149.

Pierroutsakos S.L., Troseth G.L. (2003), Video verité: Infants' manual investigation of objects on video, „Infant Behavior and Development”, nr 26(2), s. 183-199.

Redmond S., Pink S., Stadler J., Robinson J., Verhagen D., Rassell A. (2016), Seeing, Sensing Sound: Eye Tracking Soundscapes in Saving Private Ryan and Monsters, Inc., [w:] C.L. Reinhard, Ch. Olson (red.), Making Sense of Cinema: Empirical Studies into Film Spectators and Spectatorship, New York: Bloomsbury, s. 139-164.

Sapir E. (1978), Kultura, język, osobowość, Warszawa: Państwowy Instytut Wydawniczy.

Sitkiewicz P. (2009), Małe wielkie kino. Film animowany od narodzin do końca okresu klasycznego, Gdańsk: Słowo/Obraz Terytoria.

Smith T.J., Watching you watch movies: Using eye tracking to inform cognitive film theory, [w:] A.P. Shimamura (red.), Psychocinematics: Exploring Cognition at the Movies, New York: Oxford University Press 2013, s. 165-191.

Smith T.J., Lamont P., Henderson J.M. (2012), The penny drops: change blindness at fixation, „Perception”, nr 41, s. 489-492.

Troseth G.L. (2003), TV guide: Two-year-old children learn to use video as a source of information, „Developmental Psychology”, nr 39(1), s. 140-150.

Tyszkowa M. (1979), Sztuka dla dzieci szkolnych. Teoria - recepcja - oddziaływanie, Warszawa: PWN.

Wróblewska A. (2014), Rynek filmowy w Polsce, Warszawa: Wydawnictwo Wojciech Marzec.

\section{Akty prawne i inne dokumenty}

Programy Operacyjne PISF na rok 2019, PISF 2018.

Rozporządzenie Krajowej Rady Radiofonii i Telewizji z dnia 23 czerwca 2005 r. (Dz.U. z 2005 r., nr 130, poz. 1089).

\section{Źródła elektroniczne i internetowe}

Kotlińska M., Współczesne metody zarządzania projektem filmowym, niepublikowana praca doktorska, dostęp online: http://dspace.uni.lodz.pl/xmlui/handle/11089/30104.

Murch W., Favreau J., Movies in Your Brain, https://www.oscars.org/calendar/movies-yourbrain?fid $=25671$.

Polish Eye Tracking Conference, http://www.konferencjaet.neurodevice.pl/. 
Rozwój polskiego kina familijnego w 2017 roku, PISF, 22 stycznia 2018 [dok. elektr.], dostęp online: https://www.pisf.pl/aktualnosci/rozwoj-polskiego-kina-familijnego-w-2017-roku.

Steven Spielberg Loves Cinema, „The Sunday Times”, Culture, 20.01.2013, https://www.dcm. co.uk/news/steven-spielberg-loves-cinema.

Sukces nowego priorytetu wspierającego kino familijne, PISF, 20 grudnia 2016 [dok. elektr.], dostęp online: https://www.pisf.pl/aktualnosci/wiadomosci/sukces-nowego-priorytetu-wspierajacego-kino-familijne.

The Children's Media Conference, https://www.thechildrensmediaconference.com/events/ cmc-2019/. 